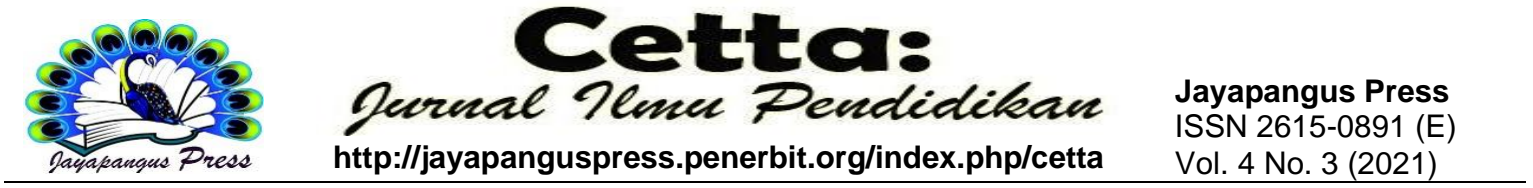

\title{
Kompetensi Profesional Guru Bahasa Indonesia Kelas IV Sekolah Dasar Katolik
}

\author{
Stefanus Tebajak Henakin ${ }^{1}$, Siprianus $\mathrm{See}^{2}$ \\ ${ }^{12}$ PGSD Universitas Flores \\ ${ }^{2}$ siprianussee@gmail.com
}

\begin{tabular}{l}
\hline Keywords: \\
\hline Indonesian \\
Teacher, \\
Professional \\
Competency. \\
\hline
\end{tabular}

\begin{abstract}
The purpose of this research is to describe the professional competence of Grade IV Indonesian teachers at The Central Ende Catholic Primary School in Ende Regency. This research is a type of descriptive qualitative research. Subjects in this study were Indonesian teachers, principals, and grade IV students. The object of this research is the professional competence of teachers of Bahasa Indonesia subjects. Data collection using interview, observation, and documentation methods. Data analysis is conducted descriptively qualitatively. Based on the results of this study, it is known that the professional competence of Indonesian teachers in grade IV in Catholic primary schools in Central Ende subdistrict is relatively good. Professional competencies that have been mastered by teachers include the ability of teachers in mastering materials, structures, concepts, and scientific mindsets, the ability of teachers in mastering the standard of competence and basic competencies of the Indonesian language, the ability of teachers in developing indonesian language learning materials creatively, and the ability of teachers in developing professionally in a sustainable manner. Thus, it can be concluded that the overall professional competence of indonesian language teachers in grade IV as threatening as Ende Tengah needs to be maintained and also organized efforts to continuously improve the professional competence of teachers in accordance with the development of science and technology.
\end{abstract}

Kata Kunci:

Guru Bahasa

Indonesia,

Kompetensi

Profesional.

\begin{abstract}
Abstrak
Tujuan penelitian ini adalah untuk mendeskripsikan kompetensi profesional guru Bahasa Indonesia kelas IV pada Sekolah Dasar Katolik Sekecamatan Ende Tengah Kabupaten Ende. Penelitian ini merupakan jenis penelitian kualitatif deskriptif. Subjek dalam penelitian ini adalah guru Bahasa Indonesia, kepala sekolah, dan siswa kelas IV. Objek penelitian ini adalah kompetensi profesional guru mata pelajaran Bahasa Indonesia. Pengumpulan data menggunakan metode wawancara, observasi, dan dokumentasi. Analisis data dilakukan secara deskriptif kualitatif. Berdasarkan hasil penelitian ini diketahui bahwa
\end{abstract}


kompetensi profesional guru Bahasa Indonesia kelas IV pada sekolah dasar katolik dii kecamatan Ende Tengah tergolong baik. Kompetensi profesional yang telah dikuasai oleh guru meliputi kemampuan guru dalam menguasai materi, struktur, konsep, dan pola pikir keilmuan, kemampuan guru dalam menguasai standar kompetensi dan kompetensi dasar bahasa Indonesia, kemampuan guru dalam mengembangkan materi pembelajaran bahasa Indonesia secara kreatif, dan kemampuan guru dalam mengembangkan keprofesionalan secara berkelanjutan. Dengan demikian dapat disimpulkan bahwa secara keseluruhan kompetensii profesional para guru bahasa Indonesia kelas IV sekecamatan Ende Tengah perlu dipertahankan dan juga secara teroganisir diupayakan untuk peningkatan kompetensi profesional guru secara kontinu sesuai dengan perkembangan IPTEK.

\section{Pendahuluan}

Salah satu komponen yang berperan penting untuk mencapai tujuan pendidikan adalah guru. Keberadaan guru yang berkompeten akan dapat menyelenggarakan proses belajar mengajar yang menyenangkan, sehingga dapat mendorong berkembangnya berbagai potensi peserta didik. Guru merupakan kunci keberhasilan sebuah lembaga pendidikan. Baik atau buruknya perilaku atau cara mengajar guru akan sangat mempengaruhi citra lembaga pendidikan. Oleh karena itu seorang guru dituntut memiliki kemampuan untuk dapat merencanakan, melaksanakan dan mengevaluasi pembelajaran dengan tetap mengacu pada materi maupun cakupan mata pelajaran yang sudah distrukturkan dalam kurikulum. Guru dalam proses belajar harus memiliki kompetensi tersendiri guna mencapai harapan yang dicita-citakan dalam melaksanakan pendidikan pada umumnya dan proses pembelajaran pada khususnya. Untuk itu dalam melaksanakan tugas dan fungsinya, guru semestinya harus dapat membina dan mengembangkan kemampuan peserta didik secara profesional dalam setiap proses pembelajaran.

Realita secara umum menunjukkan bahwa profesi yang diperankan oleh guru selama ini tergolong masih rendah, sebagian guru belum menjalankan tugasnya secara maksimal. Kepala sekolah sendiri pun belum mampu melaksanakan tugas kontrolnya secara baik dalam melakukan supervisi terhadap kinerja gurunya. Sementara itu, guru sendiripun belum melaksanakan tugasnya secara baik, dalam hal ini melaksanakan keempat kompetensii keguruannya secara baik dan penuh tanggung jawab. Dampak negatif dari kondisi ini adalah pencapaian kompetensi peserta didik secara maksimal tidak dapat terwujud yang berujung pada salah pencapaian Nilai Ujian Nasional mengalami 
penurunan hampir pada semua mata pelajaran, termasuk pada mata pelajaran Bahasa Indonesia.

Perkembangan hasil Ujian Nasional (UN) setiap tahunnya khususnya di kabupaten Ende beberapa tahun terakhir selalu mengalami kemerosotan. Hal ini berimbas pada Bupati Ende dalam berbagai kesempatan selalu menyeruhkan agar setiap satuan pendidikan berusaha untuk meningkatkan mutu pendidikan secara bertahap. Berbagai upaya telah dan sedang dilakukan oleh pemerintah kabupaten Ende melalui berbagai pembenahan dan program-program peningkatan mutu. Keprihatinan ini sebenarnya sangat beralasan karena dengan berlakunya program sertifikasi guru, seharusnya berimplikasi pada lahirnya inovasi-inovasi pembelajaran dan upaya peningkatan kualitas pendidikan dengan menerapkan model-model pembelajaran yang bersifat inovatif agar mampu meningkatkan kompetensi peserta didik yang seharusnya dicapai melalui setiap pelaksanaan kegiatan pembelajaran. Dalam membina kemampuan peserta didik, seorang guru harus memiliki kompetensi tersendiri. Kompetensi yang harus dimiliki oleh seorang guru antara lain kompetensi pedagogik, kompetensi profesional, dan kompetensi sosial. Namun dari keempat kompetensi ini yang menjadi sorotan penulis dalam penulisan ini adalah kompetensi profesional karena kompetensi ini merupakan jenis kompetensi yang sangat melekat pada diri seorang guru dan memiliki daya pengaruh yang sangat besar terhadap keberlangsungan proses pendidikan.

Kompetensi profesional merupakan penguasaan materi pembelajaran secara luas dan mendalam. Kompetensi profesional adalah kompetensi atau kemampuan yang berhubungan dengan penyelesaian tugas-tugas keguruan yang mesti dilaksanakan oleh setiap guru secara maksimal. Kompetensi profesional ini memiliki karakteristik menguasai materi ajar yang luas dan mendalam, serta menguasai struktur dan metode keilmuan bidang studi yang diajarkan. Materi yang dikuasai bukan hanya sekedar materi ajar yang diajarkan di sekolah/sesuai sebaran dalam kurikulum sekolah, melainkan pula materi yang memayunginya. Dengan menguasai materi dan memayungi, maka diharapkan guru akan mampu menjelaskan materi ajar dengan baik, dengan ilustrasi jelas dan landasan yang mapan, dan dapat memberikan contoh yang kontekstual. Di samping itu, dikuasai pula struktur keilmuan dari bidang keahliannya.

Suprihatiningrum (2013: 115) mengemukakan bahwa Kompetensi profesional merupakan kemampuan yang berkaitan dengan penguasaan materi pembelajaran bidang studi secara luas dan mendalam yang mencakup penguasaan substansi keilmuan yang 
menaungi materi kurikulum tersebut, serta menambah wawasan keilmuan sebagai guru. Profesionalitas guru merupakan titik tolak kebangkitan pendidikan. Usaha untuk mendorong terwujudnya guru profesional mesti terus dilakukan. Ahmad Sanusi dalam Asmani (2011: 58-59) menyebutkan sepuluh ciri guru profesional, yakni: fungsi dan signifikansi sosial, keterampilan dan keahlian, perolehan keterampilan dilakukan secara rutin dan bersifat pemecahan masalah, batang tubuh ilmu, masa pendidikan, aplikasi dan sosialisasi nilai-nilai profesional, kode etik dalam memberikan pelayanan kepada klien, kebebasan dalam memberikan judgment, tanggung jawab profesional dan otonomi, pengakuan dan imbalan.

Selanjutnya Soedijarto dalam Asmani (2011: 59) mengatakan bahwa guru profesional itu harus memiliki enam kriteria sebagai berikut: memahami peserta didik dengan latar belakang dan kemampuannya, menguasai disiplin ilmu sebagai sumber bahan belajar, dan sebagai realms of meaning and ways of knowing, menguasai bahan pelajaran. memiliki wawasan kependidikan yang mendalam, menguasai rekayasa dan teknologi pendidikan, berkepribadian dan berjiwa Pancasila. Sanjaya 2006 dalam Istiqomah dan Sulton (2013: 158) menyatakan bahwa kompetensi profesional guru adalah kompetensi atau kemampuan yang berhubungan dengan penyelesaian tugas-tugas keguruan. Oleh karena itu, tingkat keprofesionalan seorang guru dapat dilihat dari kompetensinya. Lebih lanjut Sanjaya menguraikan kompetensi profesional yang harus dimiliki oleh seorang guru sebagai berikut: kemampuan untuk menguasai landasan kependidikan, kemampuan dalam bidang psikoloogi pendidikan, kemampuan dalam penguasaan materi pelajaran sesuai dengan bidang studi yang diajarkannya, kemampuan dalam mengaplikaksikan berbagai metodologi dan strategi pembelajaran, kemampuan merancang dan melaksanakan evaluasi pembelajaran, keamampuan dalam menyusun program pembelajaran, kemampuan dalam melaksanakan unsur-unsur penunjang, misalnya paham akan administrasi sekolah, bimbingan, dan penyuluhan, kemampuan dalam melaksanakan penelitian dan berpikir ilmiah untuk meningkatkan kinerja.

Selain itu Mulyasa (2012:135-136) juga mengemukakan ruang lingkup kompetensi profesional guru sebagai berikut: mengerti dan dapat menerapkan landasan kependidikan baik filosofi, psikologis, sosiologis, dan sebagainya; mengerti dan dapat menerapkan teori belajar sesuai taraf perkembangan peserta didik; mampu menangani dan mengembangkan bidang studi yang menjadi tanggung jawabnya; mengerti dan dapat menerapkan metode pembelajaran yang bervariasi; mampu mengembangkan dan 
menggunakan berbagai alat, media dan sumber belajar yang relevan; mampu mengorganisasikan dan melaksanakan program pembelajaran; mampu melaksanakan evaluasi hasil belajar peserta didik; mampu menumbuhkan kepribadian peserta didik. Alma (2010:127) mengemukakan bahwa guru profesional yaitu guru yang tahu mendalam tentang apa yang diajarkan, mampu mengajarkannya secara efektif, efisien, dan berkepribadian mantap. Guru yang bermoral tinggi dan beriman tingkah lakunya digerakkan oleh nilai-nilai luhur.

Dengan demikian berdasarkan uraian di atas oleh beberapa ahli tentang kompetensi profesionalitas guru, jika kita hubungkan dengan guru yang mengasuh mata pelajaran bahasa Indonesia pada tingkat sekolah dasar, sebagai guru tentu harus dapat menerapkan kompetensi profesionalnya sesuai dengan hakikat, karakter, dan ciri guru yang memiliki profesionalitas pada pembelajaran bahasa Indonesia. Richards (2011: 25) menyatakaan bahwa adanya dua karakteristik dalam sebuah komunitas praktek yang berkenaan dengan pengajaran bahasa. Lebih jelasnya beliau mengemukakan pendapatnya sebagai berikut: Language teaching is sometimes considered a solitary and private activity, something we do within the confines of our own classrooms. But this is a narrow and self-centered view of teaching that fails to capitalize on the potential for learning and growth that comes from participating in a community of teachers having shared goals, values, and interests. The school or the teaching context becomes a learning community, and its members constitute a community of practice. Ini artinya bahwa pembelajaran bahasa Indonesia adalah pembelajaran yang amat penting, karena siswa belajar bahasa bukan untuk dirinya sendiri melainkan untuk dapat berkomunikasi secara baik dengan orang lain. Karena pembelajaran bahasa Indonesia ini melibatkan siswa usia 6-12 tahun, maka menurut Subana dan Sunarti (2011: 268-272) membagi pembelajaran Bahasa Indonesia di sekolah dasar dalam dua kelompok, yakni pembelajaran Bahasa Indonesia untuk siswa pemula dan pembelajaran Bahasa Indonesia untuk siswa lanjutan. Dengan demikian dalam merencanakan, melaksanakan dan mengevaluasi serta mengembangkan kualitas pembalajaran bahasa Indonesia tentu sangat membutuhkan guru yang profesional.

\section{Metode}

Jenis penelitian ini adalah penelitian kualitatif deskriptif. Penelitian ini terfokus pada upaya mengungkap tentang kompetensi profesional guru Bahasa Indonesia kelas IV 
Sekolah Dasar Katolik sekecamatan Ende Tengah Kabupaten Ende. Sehubungan dengan itu, maka jenis penelitian yang digunakan adalah penelitian survei dengan data yang disajikan secara deskriptif eksploratif. Subjek dalam penelitian ini adalah semua guru, kepala sekolah, dan siswa Sekolah Dasar Katolik di kecamatan Ende Tengah kabupaten Ende. Metode yang diterapkan untuk mengumpulkan data dalam penelitian ini, yaitu pengamatan, wawancara, dan telaah dokumen. Tekniks analisis data Hasil penelitian cara mendeskripsikan data hasil penelitian dengan menggunakan kalimat atau kata-kata verbal. Secara keseluruhan, data tersebut dianalisis dengan teknik analisis deskriptif kualitatif, yang merujuk pada model analisis yang dikembangkan oleh Milles dan Huberman, mulai dari pengumpulan data, reduksi data, penyajian data, dan menyimpulkan.

\section{Hasil dan Pembahasan}

\section{Hasil Penelitian}

a. Kemampuan Guru dalam Menguasai Materi Bahasa Indonsia sesuai Struktur, Konsep, dan Pola Pikir Keilmuan

Data deskriptif berikut menggambarkan kemampuan guru SDK di Kecamatan Ende Tengah dalam menguasai materi Bahasa Indonesia, yaitu data yang diperoleh dari guru Bahasa Indonesia di SDK Ende 8 yang menyatakan bahwa:

Saya menguasai materi Bahasa Indonesia karena saya sebagai guru Bahasa Indonesia harus dapat menggunakan bahasa Indonesia dengan baik dan benar baik dalam pembelajaran maupun untuk tujuan komunikatif lainnya. Saya menguasai materi Bahasa Indonesia karena saya mempelajari buku EYD dan juga buku lain yang mendukung pendalaman atau penguasaan materi misalnya yang menyangkut Tata Bahasa Indonesia dan saya terus melakukan latihan untuk semua aspek keterampilan bahasa. Sehubungan dengan hal tersebut saya mengapresiasi karya sastra Indonesia dengan melatih siswa untuk menulis karangan, puisi, dan sebagainya (Hasil wawancara dengan Yosef Soter Rapu, tanggal 15 Mei 2013).

Data di atas diperkuat dengan penuturan Kepala SDK Ende 8 sebagai berikut:

Saya lihat guru Bahasa Indonesia di sini dapat menyajikan pembelajaran dengan baik, itu jelas karena menguasai materi. Ini karena selalu saya tekankan agar guruguru dalam menyajikan materi pembelajaran haruslah berdasarkan RPP sehingga materi tepat sasaran (Hasil wawancara dengan Aloysius Bhero tanggal $14 \mathrm{Mei}$ 2013).

Dari pernyataan di atas tersirat pesan bahwa dengan RPP guru menjadi lebih terarah dalam persiapan dan penguasaan materi pembelajaran. RPP sebagai pedoman 
langkah pembelajaran sudah harus dipersiapkan bersamaan dengan perangkat pembelajaran lainnya. Melalui materi dan sumber belajar yang telah ditetapkan dalam RPP, guru mampu mempersiapkan sejak lebih awal tentang materi yang akan diajarkan, sehingga selain pengusaannya lebih baik juga lebih tepat sasaran dalam rangka mencapai kompetensi dasar siswa yang akan dicapai sesuai kurikulum.

Mengenai upaya guru untuk lebih menguasai materi pembelajaran, banyak hal yang dapat dilakukan oleh guru. Guru Bahasa Indonesia kelas IV di SDK Ursula menyatakan:

Untuk dapat menguasai keterampilan berbahasa baik dalam aspek menyimak, membaca, mendengarkan, berbicara serta menulis saya banyak membaca bukubuku, dan berlatih sendiri, dan saya mendalaminya dengan kuliah lagi (Hasil wawancara dengan Hendrika Maria Mendriani Jeen, tanggal 24 Mei 2013).

Senada dengan pernyataan di atas dikemukakan oleh responden di SDK Ende 3 sebagai berikut:

Sebagai guru saya berusaha untuk lebih menguasai materi pembelajaran. Untuk itu saya banyak membaca buku-buku untuk menambah pengetahuan serta terus berlatih dan belajar langsung dalam kehidupan sehari-hari atau melalui acaraacara yang cocok di televisi yaitu yang mendukung keterampilan berbahasa (Hasil wawancara dengan Sala Maria Goreti, tanggal 22 Mei 2013).

Dari data deskriptif di atas diketahui semangat guru-guru di Kecamatan Ende Tengah khususnya dalam hal ini guru Bahasa Indonesia dalam upaya mendalami ilmu yang mendukung tugas mengajarnya. Dengan terus memperdalam ilmu yang dibutuhkan dalam tugasnya, guru-guru makin menguasai materi pelajaran dengan pemahaman struktur, konsep, dan pola pikir keilmuan yang makin baik.

b. Kemampuan Guru dalam Menguasai Standar Kompetensi dan Kompetensi Dasar Mata Pelajaran Bahasa Indonesia

Mengenai data tentang kemampuan guru dalam menguasai standar kompetensi dan kompetensi dasar mata pelajaran Bahasa Indonesia, di antaranya peneliti dapatkan dari seorang responden di SDK Ende 8 dengan pernyataannya sebagai berikut:

Untuk memahami standar kompetensi dan kompetensi dasar mata pelajaran Bahasa Indonesia, saya melihatnya melalui kurikulum dan silabus yang selain memuat SK dan KD juga memuat tujuan pembelajaran. Setelah saya memahaminya terlebih dahulu, barulah saya membuat rancangan pembelajaran (Hasil wawancara dengan Yosef Soter Rapu, tanggal 15 Mei 2013).

Berdasarkan data di atas adalah hal yang logis bila guru yang bersangkutan dapat mempersiapkan materi yang sesuai dengan kompetensi dasar yang harus dicapai siswa. Dengan waktu persiapan yang lebih longgar, guru dapat mencari sumber belajar lain 
sebagai pelengkap. Hal ini dimaksudkan agar penguasaan materinya makin atau lebih baik sehingga penyajiannya dalam proses pembelajaran juga semakin baik. Ini berarti bahwa pemahaman standar kompetensi dan kompetensi dasar siswa berdampak pada penyajian materi pembelajaran secara baik. Keadaan di SDK Ende 8 mengenai hal tersebut dikemukakan oleh Kepala SDK Ende 8 sebagai berikut:

Guru Bahasa Indonesia di sini menguasai SK dan juga KD, ini dapat dilihat saat guru menyajikan materi. Karena guru dapat memahami SK dan KD, maka ia dapat melaksanakan kegiatan pembelajaran secara baik pula. Selaku kepala sekolah saya memang menekankan agar sebelum guru masuk kelas, guru menggunakan RPP dan silabus sehingga dalam menyajikan materi sesuai dengan yang diharapkan dalam silabus (Hasil wawancara dengan Aloysius Bhero, tanggal 14 Mei 2013).

Sementara itu data dari responden di SDK Ursula mengemukakan pernyataan sebagai berikut:

Saya memahami SK, KD, dan tujuan pada mata pelajaran Bahasa Indonesia sekolah dasar dengan cara saya membaca dulu, kemudian saya menemukan kata kuncinya apa, di situ kemudian saya buat dalam silabus, RPP, perangkat pembelajaran itu (Hasil wawancara dengan Hendrika Maria Mendriani Jeen, tanggal 24 Mei 2013)

Dari pernyataan di atas dapat diketahui bahwa guru yang bersangkutan tersebut bukan hanya memahami SK dan KD namun bahkan mampu membuat silabus sendiri untuk RPPnya. Pernyataan tersebut dikuatkan oleh pernyataan kepala SDK Ursula berikut:

Guru Bahasa Indonesia di sini mampu memahami SK, KD, dan tujuan pada mata pelajaran Bahasa Indonesia SD. Hal ini terlihat melalui penerapannya di kelas. Karena guru mampu memahaminya, maka ia pun dapat menerapkannya di kelas secara baik. Selaku kepala sekolah, saya membenahi perpustakaan dengan memperlengkapi buku, agar guru mampu mengembangkan media dan sumber belajar, sehingga ia dapat lebih baik lagi dalam menyajikan pembelajaran di kelas (Hasil wawancara dengan Sr. Herlina Nogo Manuk, OSU, tanggal 28 Mei 2013). Sementara itu, dari SDK Paupire diperoleh informasi sebagaimana dinyatakan oleh kepala sekolah sebagai berikut:

Guru Bahasa Indonesia di sini mampu memahami SK, KD, dan tujuan mata pelajaran SD. Itu terbukti dari kemampuan guru untuk menyusun sendiri perangkat pembelajarannya secara baik dan lengkap. Selaku kepala sekolah, agar guru yang bersangkutan dapat menyajikan pembelajaran sebaik mungkin, saya berusaha mengembangkan media dan sumber belajar dengan berlangganan Koran (Hasil wawancara dengan Martina Dhiu, tanggal 20 Mei 2013).

Data lainnya tentang kemampuan menguasai SK dan KD serta tujuan mata pelajaran dikemukakan oleh kepala SDK Ende 3 dengan pernyataannya sebagai berikut: 
Saya lihat guru di sini mampu memahami SK, KD, dan tujuan mata pelajaran terbukti dengan kemampuannya menyusun perangkat pembelajaran secara baik, termasuk guru Bahasa Indonesia. Selaku kepala sekolah, saya harus membantu guru-guru tersebut dalam menyediakan media dan sumber belajar lain. Saya berharap dengan adanya tambahan media dan sumber belajar, akan tercipta pendidik yang kreatif, karena untuk menciptakan siswa yang kreatif diawali dengan menciptakan pendidik yang kreatif (Hasil wawancra dengan Sura Ambrosius, tanggal 22 Mei 2013).

Dari data-data yang terurai di atas, diketahui bahwa guru-guru Bahasa Indonesia SDK di kecamatan Ende Tengah umumnya mampu memahami standar kompetensi, kompetensi dasar, dan tujuan mata pelajaran SD.

c. Kemampuan Guru dalam Mengembangkan Materi Pembelajaran Bahasa Indonesia Secara Kreatif

Guru mengembangkan materi pembelajaran melalui berbagai cara. Ada guru yang memilih materi dengan pertimbangan disesuaikan dengan usia anak, dan lebih menyenangkan anak didik. Pengembangan materi yang sifatnya sederhana dan mudah dipahami oleh anak-anak. Ada pula yang memilih pengembangan materi dengan pertimbangan tujuan pembelajaran. Materi pelajaran perlu dikembangkan karena pada tingkat implementasi, suatu materi tetap harus memperhatikan keadaan anak didik serta sarana atau media pembelajaran yang tersedia.

d. Kemampuan Guru dalam Mengembangkan Keprofesionalan Secara Berkelanjutan dengan Melakukan Tindakan Reflektif

Guru mengembangkan kemampuan profesional melalui tindakan reflektif. Jika ada keluhan guru, direfleksikan guna mendapatkan solusi. Guru dalam mengembangkan keprofesionalan secara berkelanjutan dengan melakukan tindakan reflektif. Guru memperbaiki pola mengajarnya di kelas, PTK dilakukan secara sederhana. Guru memanfaatkan itu untuk melihat dan merubah pola keguruannya dalam mengajar. Misalnya gayanya, metodenya, atau juga sikapnya dalam mengajar, guru meneliti sendiri. Pengembangan profesionalisme guru juga dilakukan dengan melibatkan guru dalam KKG mata pelajaran, guru sangat disiplin. Guru juga melatih diri tentang penggunaan bahasa anak yang bercampuran antara bahasa Indonesia dengan bahasa daerah, kebiasaan sopan-santun anak, kepaduan dalam berbahasa (cara menyampaikan maksud secara utuh), dan sikap orang tua yang melepaskan tanggung jawab sepenuhnya kepada pihak sekolah. Pengembangan profesional guru dilakukan oleh setiap guru Bahasa Indonesia dengan mengikuti seminar, dan latihan. Namun guru juga melakukan penelitian tindakan 
kelas (PTK) untuk meningkatkan kualitas pembelajaran ataupun prestasi belajar. PTK umumnya dilakukan dalam rangka tugas kuliah oleh guru yang sedang mengikuti tugas belajar, sekaligus untuk memperbaiki pembelajaran.

\section{Pembahasan}

Kompetensi profesional ini berkenaan dengan kemampuan guru dalam menguasai materi ajar secara luas dan mendalam, serta menguasai struktur dan metode keilmuan bidang studi yang diajarkan. Kompetensi profesional guru merupakan salah satu dari kompetensi yang harus dimiliki oleh setiap guru dalam jenjang pendidikan apapun. Dalam penelitian ini, penulis mengelompokkan kompetensi profesional menjadi empat (4) bagian yang dapat dijabarkan sebagai berikut:

a. Kemampuan Guru dalam Menguasai Materi Bahasa Indonsia sesuai Struktur, Konsep dan Pola Pikir Keilmuan

Kemampuan guru dalam menguasai materi pelajaran tampak dari kemampuan guru dalam memahami standar kompetensi, kompetensi dasar, dan tujuan pada Mata Pelajaran Bahasa Indonesia kelas IV Sekolah Dasar serta kemampuan guru dalam mengembangkannya. Kemampuan guru dalam memahami standar kompetensi dan kompetensi dasar tercermin dari kemampuannya dalam menyusun Rencana Pelaksanaan Pembelajaran (RPP) dan silabus. Di dalam RPP selalu mencantumkan standar kompetensi dan kompetensi dasar yang ingin dicapai dalam setiap kegiatan pembelajaran. Pada saat yang sama, guru juga dituntut mampu mengembangkan bahan ajar sesuai dengan kemampuan siswa. Selain itu, kemampuan guru pun tergambar melalui kemampuannya dalam memahami dan menguasai materi pembelajaran yang akan diajarkan. Di sini kemampuan kognitif guru mutlak berperan. Saud (2011: 97) mengemukakan bahwa guru profesional paling tidak mempunyai ciri-ciri sebagai berikut; mempunyai komitmen pada proses belajar siswa; menguasai secara mendalam materi pelajaran dan cara mengajarkannya; mampu berpikir sistematis tentang apa yang dilakukannya dan belajar dari pengalamannya; dan merupakan bagian dari masyarakat belajar dalam lingkungan profesinya yang memungkinkan mereka untuk selalu meningkatkan profesionalismenya.

b. Kemampuan Guru dalam Menguasai Standar Kompetensi dan Kompetensi Dasar Mata Pelajaran Bahasa Indonesia 
Standar kompetensi dan kompetensi dasar merupakan acuan bagi guru dalam menyelenggarakan pembelajaran. Kemampuan guru dalam menguasai standar kompetensi dan kompetensi dasar mata pelajaran Bahasa Indonesia dapat dilakukan guru dengan mencari sumber belajar lain untuk pelengkap. Hal ini dimaksudkan agar penguasaan materinya makin atau lebih baik sehingga penyajiannya dalam proses pembelajaran juga semakin baik. Ini berarti bahwa pemahaman standar kompetensi dan kompetensi dasar siswa berdampak pada penyajian materi pembelajaran secara baik. Dalam hal ini, guru sudah semestinya mampu menguasai standar kompetensi dan kompetensi dasar mata pelajaran Bahasa Indonesia itu sendiri.

c. Kemampuan Guru dalam Mengembangkan Materi Pembelajaran Bahasa Indonesia Secara Kreatif

Guru mengembangkan materi pembelajaran melalui berbagai cara. Ada guru yang memilih materi dengan pertimbangan (disesuaikan) dengan usia anak, dan lebih menyenangkan anak didik. Materi pembelajaran merupakan bagian atau salah satu komponen dari kurikulum pendidikan. Oleh karena itu, pengembangan bahan ajar merupakan sesuatu yang kompleks meliputi tujuan, kompetensi, sumber materi pembelajaran, kemampuan guru, dan sebagainya. Tujuan pendidikan pada masingmasing mata pelajaran merupakan bagian kecil dari upaya pencapaian tujuan pendidikan di tingkat satuan pendidikan yang pada akhirnya menjadi bagian dari upaya mencapai tujuan pendidikan di tingkat nasional. Freidson (2001) dalam Shah, dkk (2008: 537) mengutip Freidson yang memberikan batasan tentang profesional sebagai berikut: The notion of a profession is that of a discrete group of practitioners who possess a specialized body of knowledge allowing them to engage in a narrow field of work. Sociologists have identified other prerequisites before a field can reasonably be called a profession, including an identified social need, an internal ethical framework, internally set standards for admission into the field, and a social mandate allowing the field to set these admissions standards.

Kompetensi profesional merupakan penguasaan materi pembelajaran secara luas dan mendalam. Kompetensi profesional adalah kompetensi atau kemampuan yang berhubungan dengan penyelesaian tugas-tugas keguruan yang mesti dilaksanakan oleh setiap guru secara maksimal. Kompetensi profesional ini memiliki karakteristik menguasai materi ajar yang luas dan mendalam, serta menguasai struktur dan metode keilmuan bidang studi yang diajarkan. Materi yang dikuasai bukan hanya sekedar materi 
ajar yang diajarkan di sekolah/sesuai sebaran dalam kurikulum sekolah, melainkan pula materi yang memayunginya. Dengan menguasai materi dan memayungi, maka diharapkan guru akan mampu menjelaskan materi ajar dengan baik, dengan ilustrasi jelas dan landasan yang mapan, dan dapat memberikan contoh yang kontekstual. Di samping itu, dikuasai pula struktur keilmuan dari bidang keahliannya. Pengembangan materi yang sifatnya sederhana dan mudah dipahami oleh anak-anak. Adapula yang memilih pengembangan materi dengan pertimbangan tujuan pembelajaran. Materi pelajaran perlu dikembangkan karena pada tingkat implementasi, suatu materi tetap harus memperhatikan keadaan anak didik, sarana atau media pembelajaran yang tersedia.

d. Kemampuan Guru dalam Mengembangkan Keprofesionalan Secara Berkelanjutan dengan Melakukan Tindakan Reflektif

Kemampuan profesional harus terus dikembangkan oleh setiap guru. Artinya guru harus memiliki kemampuan untuk mengembangkan dirinya, baik secara individu maupun secara bersama-sama dalam satu wadah. Salah satu wadah pembinaan yaitu Kelompok Kerja Guru (KKG). Dalam hal ini, guru-guru di Ende Tengah sudah aktif dalam pengembangan profesional guru melalui KKG. Pengembangan profesional guru dilakukan oleh setiap guru Bahasa Indonesia dengan mengikuti seminar, dan latihan. Di samping itu, guru juga melakukan Penelitian Tindakan Kelas (PTK) untuk meningkatkan kualitas pembelajaran ataupun prestasi belajar peserta didiknya. Majid (2008: 9-11) mengungkapkan bahwa proses pengembangan kompetensi guru dapat dilakukan melalui tiga hal, yaitu penelitian, pengembangan, dan manajemen mutu guru. 1) Penelitian; Sekurang-kurangnya ada tiga jenis upaya penelitian yang dilakukan dalam kaitan dengan pengembangan mutu guru, yakni: a) Mengidentifikasi masalah pendidikan yang dihadapi terutama tentang mutu kinerja guru, b) Mengkaji prakondisi yang perlu dipenuhi untuk dapat menerapkan suatu standar kompetensi guru dalam sistem yang ada, c) Penelitian yang melekat di dalam pengembangan standar itu sendiri untuk mengetahui efektivitas atau kelaikan dari standar yang sedang dikembangkan dalam menghasilkan standar baku kompetensi guru. 2) Pengembangan; Upaya pengembangan dalam rangka menghasilkan inovasi yang tepat untuk diterapkan dalam sistem yang ada, merupakan tahapan yang sangat penting dan kritikal. Ada beberapa hal yang perlu mendapat perhatian yang serius dalam upaya pengembangan standar kompetensi guru, yakni: a) Kejelasan permasalahan dan tujuan yang ingin dicapai dari profesi guru, antisipasi kendala yang bakal dihadapinya, identifikasi alternatif-alternatif pemecahan, serta pengembangan alternatif 
yang dipilih dalam skala terbatas, b) Permasalahan yang jelas serta tujuan yang spesifik, jika perlu dilengkapi dengan kriteria keberhasilan yang dijadikan ukuran, merupakan titik awal yang sangat penting dalam upaya pengembangan standar kompetensi guru. Permasalahan maupun tujuan yang ingin dicapai hendaknya dirumuskan sedemikian rupa sehingga membuka peluang bagi diterapkannya standar kompetensi applicable, c) Antisipasi kendala, merupakan langkah yang tidak dapat diabaikan dalam proses pengembangan ini. Pemahaman terhadap kendala yang ada akan sangat berguna dalam proses mengidentifikasikan maupun menyeleksi alternatif pemecahan atas standar kompetensi yang akan dikembangkan, d) Melalui proses identifikasi dan seleksi berbagai alternatif pemecahan, akan dapat dihasilkan standar kompetensi yang telah diperhitungkan kekuatan maupun kelemahannya ditinjau dari permasalahan dan tujuan yang diinginkan maupun kendala-kendala yang ada. Dengan kata lain, langkah ini akan sangat berguna bagi optimalisasi efektivitas maupun kelaikan dari standar kompetensi yang akan dikembangkan, e) Sekalipun uji coba suatu standar kompetensi dalam skala terbatas, kadang-kadang mengandung kelemahan (terutama dalam prediksi kelaikan large scale implementation. Upaya pengembangan dalam skala terbatas ini tampaknya masih tetap diperlukan dalam fase-fase awal pengembangan standar. Hal yang perlu diperhatikan adalah agar karakteristik lingkungan terbatas dimana standar kompetensi guru yang akan dikembangkan hendaknya diupayakan sedekat mungkin dengan karakteriistik dunia nyata (the real world), bukan merupakan situasi yang sangat berbeda dengan lingkungannya. 3) Manajemen mutu guru; Sekurang-kurangnya terdapat dua hal penting yang perlu diperhatikan berkenaan dengan manajemen peningkatan mutu guru dengan standar kompetensinya; pertama, adalah upaya melibatkan berbagai pihak terkait sedini mungkin, dan kedua adalah penerapan proses diseminasi secara bertahap. Adanya peran serta aktif dari berbagai pihak terkait sedini mungkin dalam proses pengembangan mutu guru akan membuat standar kompetensi yang mengiringinya tidak terisolir dari dunia nyata, sehingga proses transisi dari tahap pengembangan ke tahap pelaksanaan (implementasi) para guru akan dapat berjalan dengan lancar.

\section{Kesimpulan}

Kompetensi profesional merupakan kemampuan guru dalam konteks penguasaan materi ajar secara luas dan mendalam, serta penguasaan struktur dan metode keilmuan bidang studi yang diajarkan. Kompetensi profesional guru merupakan salah satu dari 
kompetensi yang harus dimiliki oleh setiap guru dalam jenjang pendidikan apapun. Dalam penelitian ini, penulis dapat mengemukakan beberapa kesimpulan berkenaan dengan kompetensi profesional guru Bahasa Indonesia Sekolah Dasar Katolik Sekecamatan Ende Tengah sebagai berikut: a) Guru mampu menguasai materi, struktur, konsep dan pola pikir keilmuan yang mendukung mata pelajaran Bahasa Indonesia, b) Guru mampu menguasai Standar Kompetensi dan Kompetensi Dasar mata pelajaran Bahasa Indonesia, c) Guru mampu mengembangkan materi pembelajaran Bahasa Indonesia secara kreatif, d) Guru mampu mengembangkan keprofesionalan secara berkelanjutan dengan melakukan tindakan reflektif.

\section{Daftar Pustaka}

Alma, B. (2010). Guru profesional menguasai metode dan terampil mengajar. Bandung: Alfabeta.

Asmani, J. M. (2011). Tips sukses plpg (pendidikan dan latihan profesi guru). Yogyakarta: Diva Press.

Majid, A. (2008). Perencanaan pembelajaran (mengembangkan standar kompetensi guru) Bandung: PT Remaja Rosdakarya.

Mulyasa, E. (2012). Standar kompetensi dan sertifikasi guru. Bandung: PT Remaja Rosdakarya.

Saud, U.S. (2011). Pengembangan profesi guru. Bandung: Alfabeta.

Richards, J.C. (2011). Competence and performance in language teaching. New York: Cambridge University Press.

Shah, N., Anderson, J. \& Holly J. H. (2008). Teaching Professionalism: a tale of three schools. Perspectives in Biology and Medicine, volume 51, number 4

Subana dan Sunarti. 2011. Strategi belajar mengajar bahasa indonesia. Bandung: CV Pustaka Setia.

Suprihatiningrum, J. (2013). Guru profesional (pedoman, kinerja, kualifikasi, dan kompetensi guru). Jogjakarta: Ar-Ruzz Media. 